\title{
Victim Evaluations of Face-to-Face Restorative Justice Conferences: A Quasi-Experimental Analysis
}

\author{
Heather Strang* \\ Australian National University
}

\author{
Lawrence Sherman, Caroline M. Angel, Daniel J. Woods, and Sarah Bennett \\ University of Pennsylvania
}

\author{
Dorothy Newbury-Birch and Nova Inkpen \\ Australian National University
}

One major goal of face-to-face restorative justice $(R J)$ is to help heal the psychological harm suffered by crime victims (Braithwaite, 2002). Substantial evidence from randomized controlled trials (RCTs) has shown that this can be accomplished (Strang, 2002) and more trials are underway (Sherman \& Strang, 2004). These outcomes are even more clearly, if less rigorously, demonstrated through retrospective interviews of victims about their feelings before and after RJ took place. We review the responses of victims $(N=210)$ who participated in trials in Canberra (Australia) and in London, Thames Valley, and Northumbria (UK). Despite substantial variations in offense types, social contexts, nation and race, before-after changes revealed by qualitative and quantitative data are all in the same beneficial direction.

The costs of crime are rarely calculated to include its full impact on crime victims. The British government, for example, employs a formula to estimate crime costs that includes property loss, health services, and victim support services, but makes only a crude estimation of the emotional costs entailed in victimization with no mention of such victim effects as fear of the offender repeating the crime, emotions of anger or grievance, or loss of a general sense of trust in others (Brand

\footnotetext{
* Correspondence concerning this article should be addressed to Heather Strang, Centre for Restorative Justice, Regulatory Institutions Network, Research School of Social Sciences, Australian National University, Canberra, A.C.T. 0200, Australia [e-mail: heather.strang@anu.edu.au].
} 
\& Price, 2000). Nor do their calculations include a full estimate of the medical consequences of posttraumatic stress symptoms (PTSS), which could include such untested hypotheses as reduced immune function, higher rates of disease, greater use of medical services, and higher mortality from cancer or cardiovascular disease. Angel's (2005) evidence from interviewing robbery and burglary victims in London finds elevated levels of PTSS, high enough to make such hypotheses plausible.

Despite periodic spurts of discussion of crime victims by national leaders, governments and the press continue to ignore victims in most discussions of crime policy. Just one year after the British Prime Minister declared the aim of "putting victims at the centre," newspapers heaped scorn on restorative justice (RJ) when an Oxford University study reported no crime reducing — nor any crime increasingeffects of RJ in some 30,000 cases in the Thames Valley area (Wilcox, Young, \& Hoyle, 2004). One headline said "Saying Sorry Does Not Work" (Daily Telegraph, 4 January, 2005); another said "Thugs Who Say Sorry Reoffend" (Daily Mail, 4 January, 2005; see also The Scotsman, The Guardian, The Independent, 4 January, 2005). Not one of those articles asked whether victims derived any benefit from a process that had no adverse impact on crime.

The answer to that question is clearly yes, for at least one kind of RJ. Evidence from three countries now shows that victims can derive substantial benefits from a form of face-to-face RJ (McGarrell et al., 2000; Sherman et al., 2006; Strang, 2002; Strang \& Sherman, 2003). Many other kinds of RJ, broadly defined, have been developed and put into practice across the globe, while many other traditional forms have been in continuous operation for millennia (Braithwaite, 2002). All of them merit careful and rigorous evaluation, in order to insure that neither present nor future victims are harmed by a process that could - in theory-just as easily cause more crime or harm rather than less. Only one RJ approach, however, has been subjected to the same level of testing as a new medicine would normally be in the United States or the United Kingdom. That approach is the specific and consistent approach we describe in this article for arranging and conducting consensual (voluntary) meetings among offenders, their victims, and their respective families and supporters. This is not the only kind of face-to-face RJ, but it does share key elements with a wide variety of other face-to-face approaches that may justify conclusions about face-to-face RJ in general.

As a general distinction from Common Law retributive justice, RJ has been defined as "a process whereby all the parties with a stake in a particular offense come together to resolve collectively how to deal with the aftermath of the offense and its implications for the future" (Marshall, in McCold, 1997). While this definition has many limitations (Braithwaite, 2002, p. 11), it does identify core elements common to all RJ. Thus when an offender writes a letter of apology to a victim, or when a mediator relays oral messages between crime victims and their offenders (and vice versa), or when a mediator, victim, and offender sit in a bargaining triad 
to negotiate an exact sum of payment, they are all performing the activities in Marshall's definition. Moreover, they are all engaging in the social construction of civil society justice that may cooperate with, but is not controlled by, agents of the state.

Situated as it is between states and families, RJ occupies a space in civil society that gives it the potential to maximize the strengths of both formal justice procedure and informal social control. This is especially true of what we call a RJ conference, as distinct from other forms of face-to-face RJ in which no one else meets besides victims, offenders, and a facilitator. A conference is inherently a civil society institution in which the voluntary donation of time by persons other than crime victims or offenders provides (and constructs) the social capital (Putnam, 2000) essential to the justice process. In this form of face-to-face RJ (the focus of this article), admitted offenders and their victims are invited to assemble in a two- to three- hour conference, together with their "supporters" (usually family, friends, co-workers, or others previously known to victims or offenders).

In preparation for the conference, the facilitator who will lead the meeting explains carefully to the participants what their roles and responsibilities will be. The purpose of the conference is to hold offenders accountable for their actions, asking them to articulate responsibility for their behavior, and to agree to try to repair the harm they have caused. The conference also provides an opportunity for the victims to find out why the crime occurred, to ask questions of their offender, and to describe the full consequences of what happened. Sitting with all participants in a circle, the facilitator (most often a police officer in the research we report here) usually begins the conference by asking the offender to talk about what happened at the time of the offense. The facilitator then invites the victim to talk about the emotional and material effects of the offense. All parties usually feel anxious and apprehensive at the outset, and victims may feel angry and upset. These are often highly emotional encounters, sometimes with shouting and tears. The facilitator's role is to keep discussion focused on the incident and its aftermath while allowing participants to express their feeling directly to one another.

After the parties have said all they want to say about what happened and how they were affected, the facilitator's task is to turn discussion toward an outcome agreement aimed at repairing the harm that has occurred. This may be direct material reparation to the victim, if material harm was suffered. Sometimes the focus is on what the offender can do to prevent future offending. Almost always there is emotional restoration in the form of apologies and expressions of remorse which is what victims say they want most of all (Strang, 2002). When everyone has decided what needs to be done to make amends for the crime, all participants sign the outcome agreement and the formal part of the conference is ended. There is then usually an opportunity for everyone to talk together informally: It is often at this time that important emotional repair work takes place. 
We have included in all of our own trials some before-after measures of RJ effects on the emotions of victims randomly assigned to RJ. They are necessarily limited by their retrospective character, since they are derived from a single afteronly interview with each victim. We have been unable to employ a multi-wave before-and-after interview design due to fear of contaminating the RJ treatment itself, and fear of losing victim compliance with the intended treatment as an unintended side effect of discussing their emotions and attitudes with them in great detail prior to the RJ process. A primary purpose of that process is to discuss, in an emotionally powerful way, the effects of the crime on the victim. Thus it is not implausible that victims' reaction to an RJ conference would be affected by a social science interview on the same issues if conducted prior to the RJ conference.

Despite this limitation, the value of these retrospective data lies in the lack of face validity of the rival hypothesis that victims had already reached many of their posttreatment views prior to treatment. Given the evidence of differences between treatment and control groups after experiencing their respective treatment group conditions (Strang, 2002), the plausibility of that rival hypothesis would appear to be weakened. The short time frame between the RJ treatment and the interview (2-6 weeks) also limits the loss of reliability in recall of the events and emotions. While retrospective reinterpretation of such emotions is always possible, the central hypothesis remains worth discussing: that RJ changed the emotional states of victims just as they described them.

Whatever their limitations, the data derived from asking 210 crime victims how they react to face-to-face RJ should be of interest to both theorists of victim trauma and those interested in policies for helping victims of crime. The findings should be of even more interest if they are consistent across different countries, small and large communities, different ethnic groups, and socio-economic levels. This article presents and discusses the results of this research, after briefly reviewing the theoretical background and research designs and samples.

\section{Theoretical Background}

Theoretical formulations for RJ or related theories in criminology have focused almost exclusively on effects on repeat offending by offenders (see, for example, Braithwaite, 1989, 2002; Sherman, 1993; Tyler, 1990), with no formal theories of victim consequences. While Braithwaite, for example, provides nuanced discussions of benefits or costs of RJ as a whole, he does not suggest a detailed theoretical framework for why RJ should be expected to provide benefits to victims. Nor does Strang (2002), in the only book so far devoted entirely to empirical work on the victims' perspective on RJ.

Nevertheless, two theories from beyond criminology offer plausible rationales for predicting positive outcomes from RJ for participating crime victims. In 
psychology, cognitive behavioral therapy (CBT) research suggests that victims can benefit from extended "deconditioning" discussions of their prior traumas held in safe and controlled environments. In sociology, the theory of "interaction ritual" (IR) predicts that the emotional energy arising from a successful RJ conference will have positive benefits for victims by restoring their identity and sense of self-worth.

Extinguishing fear through cognitive behavioral therapy. Reviews of recent research indicate that CBT may be one of the most promising interventions for addressing the emotional harm that results from victimization. One particularly promising form for reducing victims' PTSS (Angel, 2005) may be therapy involving repeated exposure to anxiety-provoking stimuli. Thus victims may extinguish their fear by repeatedly reliving their trauma or confronting people involved in the trauma in safety and far from the fearful place where the event occurred (Foa \& Meadows, 1997; Rothbaum \& Foa, 1999). This treatment program is based on conditioning theory about the way fear is acquired and dissipates. Foa and Kozak (1986) hypothesize that fear is a cognitive structure that can be extinguished by deconditioning memories of the trauma through associating them with safe settings such as an RJ conference can provide.

Another element of CBT relevant to RJ conferences concerns victims' understanding of their (lack of ) responsibility for the event. Victims frequently attribute blame for the offense at least partly to themselves, if only because they believe they must have been targeted through some sign of vulnerability. They may do this as part of an attempt to make sense of a shocking and disruptive experience (Gehm, 1990), preferring to construct for themselves an apparently plausible story around their own culpability to explain events rather than to believe that they have been the subject of a random and unpredictable act. In CBT victims can talk about the events and be shown how they were not responsible for what happened to them. In Foa's research, this reassurance appears to be a crucial component in reducing stress symptoms. RJ conferences present the opportunity for victims directly to question their offenders about "why me?"- a question that arises almost every time-and to gain a great deal from hearing that they were not in fact targeted for victimization. (Of course there are occasions when indeed victims do bear at least partial responsibility for their victimization, but this was almost totally lacking among cases in the present analysis.)

Empathy for offenders and interaction ritual (IR). One sensitizing concept (Blumer, 1969) in gathering these data is victim empathy for the plight of the offender. Once thought by David Hume to be a kind of master force in human nature, or a social equivalent of gravity in Newtonian physics (Buchan, 2004), empathy is derived from putting one's mind in the frame of reference of another. Victims who never meet their offenders, or never learn much about the offenders' 
lives, may fear them as monsters. Victims who learn the life story, or at least present circumstances, of their offenders may come to understand them better. They may even empathize with the misfortunes and cruelty the offenders have suffered, literally "feeling their pain."

The structured RJ process of exchange of perspectives is an example of an IR (Collins, 2004, p. 111), in a theory that provides a plausible basis for positing the likely benefits to victims of a successful RJ encounter. Collins recent theory has not yet been tested in the kinds of controlled experiments he recommends, but he does fit many qualitative descriptions of social interaction into his formal theory. Collins defines IR as social encounters with four distinct characteristics: (1) people are physically in each others' presence and hence influenced by proximity; (2) there is a clearly defined boundary around who is participating in the ritual and who is not; (3) all participants knowingly focus on a common purpose; and (4) the participants share a common emotional mood that Collins refers to as an "entrainment" experience.

Collins suggests that the Durkheimian concept of "collective effervescence" that results from a successful IR (Durkheim, 1912/1965, as quoted in Collins, 2004, p. 34)—such as an emotionally satisfying RJ conference-causes longterm boosts in emotional energy. This in turn can manifest itself in feelings of confidence, elation, and initiative in action. Collins further suggests that it is emotional intensity, rather than content alone, that increases the likelihood of a successful IR. Whatever the dominant mood at the beginning of the interaction, emotional contagion is likely to occur that can allow ritual to change emotions from bad to good and bind all the participants together in a commitment to shared morality.

Collins sees RJ encounters as likely to be successful IRs when they contain high-intensity emotions and include all the elements the theory posits. Special importance, as a primary symbol of group solidarity, is attached to an apology by the offender to the victim. A perception by the victim that the apology is sincere will indicate whether the symbol has in fact been recognized (see Sherman et al., 2006). Victims who had lost their own self-respect because they "allowed" themselves to be victimized may regain it by hearing that they were not personally targeted for victimization and had no influence over their selection by the offender. Victims who may have felt subordinated to the physical superiority of the offender may derive a sense of moral superiority if the offender apologizes for having done something wrong. A successful IR may then give victims enough emotional energy to gain cognitive mastery of their emotions, replacing conditioned fear with rational sympathy for the offender who is often just as much a victim of externally caused harm. Thus the ritual becomes as much a process of deference exchange and cognitive analysis as a process of empathy-building. 


\section{Research Designs and Samples}

The studies in the four sites we shall report on were all designed to test the effectiveness of $\mathrm{RJ}$ in reducing repeat offending and in providing victim benefits. All were part of, or conducted in preparation for, randomized controlled trials (RCT) in which eligible cases with admitted offenders were randomly assigned to one of two conditions. In the Canberra study (the Reintegrative Shaming Experiments, otherwise known as RISE), cases of middle-level property or violent crimes that would normally be dealt with in the lower (magistrates) courts, were randomly assigned either to be prosecuted in the usual way or to be diverted to RJ instead of prosecution. In all the English studies (London, Northumbria, and Thames Valley) cases were randomly assigned either to be dealt with in the usual way, or to have RJ added to the prosecution of their case. In all four research sites, offenses involving domestic violence or containing any sexual aspect were excluded.

The Canberra sample represents the attitudes of all interviewed victims whose cases were randomly assigned to RJ and who actually attended an RJ conference. For the three English sites, data relating to Figures 1-4 were derived not from the whole sample of randomly assigned cases but instead from the cases coming into the Phase I study in the preparatory stage of the experiments, prior to launching the randomized trial. We were unable to ask these questions of victims during the randomized trials in the United Kingdom because they were the subject of an independent evaluation of our trials conducted by the University of Sheffield. In this preparatory stage in each site, cases were identified and victim and offenders approached in exactly the same manner as they were for the experiments proper, but $100 \%$ of consenting victims were offered an RJ conference in this Phase instead of the $50 \%$ assignment during the later RCT.

In addition, we report some other findings on reactions to RJ derived from calls made to victims in London and Northumbria during the RCTs who had been randomly assigned to $\mathrm{RJ}$ (Table 2). The primary purpose of these calls was to check on victims' welfare and to ensure that no harm had ensued from their participation in the conference but we took this opportunity to ask some questions about victims' general satisfaction with the process. The great majority of these calls were made by a psychiatric nurse calling from the United States who had had no direct role in the RJ program in any of the four sites.

All research sites used similar measures to study an RJ program delivered by similar people (usually police officers) trained by the same trainers to follow the same format. These similarities stood in sharp contrast to enormous differences in social context, offense types, and characteristics of victims and offenders. These differences across the four sites are described below using each site as a case profile. 
Canberra. Although it is Australia's capital, Canberra bears little resemblance to most major cities of the world. It is a new place, mostly constructed in the past 40 years, and its population of 300,000 is both better educated, better off, and younger than the rest of the country. But Canberra's predominantly middle-class, civil service workforce and their families share the city with a substantial underclass. In far-flung suburbs, disaffected young people have little to occupy them beyond the attractions of the local shopping malls. Aboriginal people are among the most marginalized: Most are remnants of local tribal groups, and others who have drifted in from smaller towns and communities, facing the kinds of problems experienced by indigenous groups in many parts of the world. The loss of traditional authority structures combined with disadvantage and deprivation result in vast Aboriginal overrepresentation in the criminal justice system.

RISE violence and property offenders were mostly drawn from these socially and economically disadvantaged sectors of the city. They were mostly male and young (under 18 years for property crime and under 30 for violent crime). About half in both experiments were first-time offenders; those with a prior record averaged 2.5 offenses each. They were mostly white though about $10 \%$ were Aboriginal (less than $2 \%$ of the population is Aboriginal). Their offenses were middle-range property crimes such as theft, burglary, auto crime, criminal damage, and violent crimes such as common assault and aggravated assault, all normally dealt with in the Magistrates Courts. All offenders asked to participate in the experiments agreed to do so: Because RISE entailed diversion from prosecution to RJ for the experimental group, there were evident advantages in being randomly assigned to RJ.

The property victims were much older and better educated than their offenders, with almost no unemployment and they included almost as many females as males. The violence victims looked somewhat more like their offenders, mostly in their mid-twenties, predominantly male with a higher-than-average unemployment rate (Strang, 2002, p. 85).

An important feature of the victims in RISE was their extraordinary willingness to attend RJ conferences when invited to do so (see Table 1). One possible reason for around $90 \%$ victim cooperation with RJ may be that Canberra is a particularly well-bonded city with a strong sense of civic duty in its population. Another reason may be the manner in which the invitation was issued, which did not seek consent but simply asked victims when it would be convenient to schedule the RJ conference. Around $90 \%$ of these victims agreed to be interviewed, so we have confidence that the views expressed by these victims are largely representative of the victims who experienced RJ.

In the Canberra experiments all RJ conferences were convened under the auspices of the Australian Federal Police, were facilitated by specially trained police officers and took place within police stations. 
London. Few places could provide a greater contrast to Canberra as a site for testing RJ than London. One of the great cities of the world with a population of more than seven million, the British capital is almost infinitely diverse in its cultural and demographic character. Great wealth is matched by great poverty and disadvantage. This is especially evident among its non-white population, many of them relatively recent arrivals to Britain. There are few more ethnically and racially mixed cities in the world. With the communication and transport difficulties found in many large cities, this diversity results in pockets of great economic deprivation and social isolation associated with high-crime areas.

The offenders who entered our London experiments had committed far more serious crimes than their Canberra counterparts. In the formal RCT they were all adults who had pleaded guilty to robbery or serious burglary whose cases were being dealt with in Crown Court rather than the lower Magistrates' Courts. Those assigned to the experimental group had RJ in addition to normal court processing. The burglars had an average of 44 prior convictions for serious crimes, while the robbers had an average of 22 prior convictions. Most had been remanded in custody to await their sentence. Offenders in the pre-random assignment data set had all pleaded guilty at either Magistrates Court or Crown Court to robbery, assault, burglary, or other property crime.

Among the burglary victims in this data set, over half were male, three-quarters were white, and they averaged 44 years of age. Of the robbery victims, just under half were male, three-quarters were white, and they averaged 25 years of age. Of the assault and property victims, about half were male and white and they averaged 23 years of age. A little over half of all victims approached agreed to take part (see Table 1), a commendable figure by English standards. In contrast to our Canberra study, RJ programs in the United Kingdom have repeatedly found a serious reluctance on the part of victims generally to participate in RJ at all, with consent rates as low as $15 \%$ (Miers et al., 2001). We attribute the comparatively high participation rates by both victims and offenders to the way in which they were approached in all our U.K. sites, with face-to-face visits, sometimes more than one, by the specially trained police facilitators who would lead the conferences, and careful explanations of the RJ program and the research.

In the London experiments all RJ conferences were convened under the auspices of the Metropolitan Police. The conferences took place either in prison (in the cases where offenders were remanded in custody) or within police stations.

Northumbria. The north-east of England has been through difficult times over the past 20 years. The economic reforms of the Thatcher era led to dramatic changes in a way of life that had survived more than 200 years, since the beginning of the Industrial Revolution. While circumstances had been tough for most of the population throughout this period, the hardships of the shipbuilding and mining industries had been ameliorated by a strong sense of community. Much of it was 
swept away with the end of this industrial base, though it survives to some extent in the economically depressed areas of Sunderland and Gateshead, the location of most of our RJ research. The population in these areas, as in the research, is almost entirely white: $95 \%$ of all victims and offenders. In contrast to the high unemployment of Sunderland and Gateshead, however, there has been a strong economic revival in Newcastle, Northumbria's major city. Now a well-known "party town," Newcastle's bars and pubs provided many of the cases of violent crime that came into our study.

In Northumbria we tested RJ with adult property and violent offenders whose cases were dealt with in the Magistrates Courts. As in London, these offenders had pled guilty and were awaiting sentence. Unlike in London, all of the offenders were free on bail. We also conducted a Phase I test (without control cases) of RJ conferences with adult offenders who had been assigned to receive a police caution for an assault. These crimes often involved ongoing disputes between victims and offenders with long prior relationships, where responsibility for the instant offense was unclear, and where there had often been a history of multiple police callouts for similar incidents.

The Northumbria Police also partnered with us in two experiments involving juvenile offenders admitting to a violent or property offense with a personal victim. All of these juveniles, under the Youth Justice Act of 1998, were given a "Final Warning" (which is to say that they would face a mandatory prosecution in court, with risk of incarceration, if they offended again). Most Final Warnings in the United Kingdom are delivered by a police supervisor in a private meeting with the offender and a parent or guardian; they can be short, emotionally shallow, or empty rituals. The experiments tested an RJ version of a Youth Final Warning: The police convened a full RJ conference to discuss the crime, with as much civil society participation as possible.

Victims in all the adult cases were in their early thirties on average and were mostly male. In the youth cases they averaged 18 years of age and were about half and half male and female. Victims of juvenile offenders were more likely to consent to participate than victims in the adult cases (see Table 1). Nevertheless, the participation rates were still high by the standards of other RJ programs in the United Kingdom (Miers et al., 2001). All conferences took place in a police station under the auspices of the Northumbria Police and were facilitated by police officers trained by the same Australian trainers as in Canberra and London.

Thames Valley. Often described as the very heart of England, the Thames Valley stretches across some of the wealthiest and most privileged parts of the country. It includes the city of Oxford as well as a myriad of small towns and villages still characterized by the traditional bonds of white, middle-class communities. But the area is also a commuter belt, with many residents making the daily trek to London. It contains middle-sized conurbations such as Reading, Slough, and Milton 
Table 1. Percent Take-Up Rates of Victims and Offenders by Experiment

\begin{tabular}{lcc}
\hline Experiment & Victims & Offenders \\
\hline Canberra RISE & & \\
$\quad$ Property & 84 & 100 \\
$\quad$ Violence & 92 & 100 \\
London & 59 & 78 \\
$\quad$ Burglary & 52 & 82 \\
$\quad$ Robbery & & \\
Northumbria & 48 & 76 \\
$\quad$ Court assault & 57 & 58 \\
$\quad$ Court property & 68 & 62 \\
$\quad$ Youth assault & 75 & 66 \\
$\quad$ Youth non-assault & & 66 \\
Thames Valley & 36 & 65 \\
$\quad$ Prison & 42 & \\
Community supervision & & \\
\hline
\end{tabular}

Keynes, each with multi-racial populations and an array of social problems. Even the smaller communities contain their share of difficulties. Gypsy "travelers" in conflict with "locals," pub brawls, and neighborhood feuds provided a steady flow of cases into our experiments.

All offenders in the Thames Valley sample were adults who had been convicted of a violent offense and had been sentenced either to a term of imprisonment or to a community supervision order for that offense. Victims were predominantly white males and on average in their early thirties. Perhaps because of the seriousness of the offense, they were more reluctant to participate in RJ than were the victims in the other studies (see Table 1). Unlike the others, the Thames Valley program was multi-agency in origin though primarily supported by the Probation Service, and the facilitators came from a variety of nonpolice backgrounds. They included probation officers, prison officers, victim advocates, and mediators with social welfare backgrounds. However, all had undergone exactly the same training as the police facilitators in the other sites. If the offender was in prison, the RJ conference was conducted in prison. If the offender was under community supervision, the RJ conferences were held in community centers, village halls, or probation premises.

\section{Victim Interviews}

The cases we report on in Canberra include all victims randomly assigned to $\mathrm{RJ}$ where the victim attended RJ: This totaled 89 , consisting of 51 property victims and 38 violence victims, of whom 80 were interviewed (90\% response rate).

In London we report on the $47 \mathrm{RJ}$ cases in the pre-random assignment data set only, and victims were interviewed in 35 of them (65\% response rate). These 
consisted of 22 burglary victims, seven robbery victims and six victims of assault and property crime .

In Northumbria we report on the $89 \mathrm{RJ}$ cases in the pre-random assignment data set only and victims were interviewed in 62 of them ( $70 \%$ response rate). These included 24 victims of assault and property crime dealt with in the Magistrates Courts, 24 cases of youths dealt with by the police at the Final Warning stage, and 14 cases of adult assaults resulting in a caution.

In the Thames Valley we report on the 43 cases in the pre-random assignment data set only and victims were interviewed in 33 of them ( $77 \%$ response rate). These consisted of 11 victims whose offenders had been convicted of a violent crime for which they were serving a term of imprisonment and 22 victims whose offenders had been sentenced to a community supervision order (probation) for the violent crime.

Victims are usually more wary of participating in RJ than offenders are, though this may be related to social context, to the seriousness of the offense, and the way in which they are approached. The exception is in the Northumbria "Youth" experiments where victims were more willing to take part than their offenders were. The evidence from this site and from RISE indicates that victims may be more inclined to agree to RJ when their offender is a youth rather than an adult.

The results reported below on victims' reactions to their offenders before and after RJ, come from the Canberra property and violence experiments and the prerandom assignment studies in each of the three English sites. In each site victims who had actually attended an RJ conference were asked

1. whether they were afraid of their offender before and after the RJ conference;

2. whether they felt angry with their offender before and after the RJ conference;

3. whether they felt sympathetic towards their offender before and after the RJ conference.

In addition, the London data alone provide four-point estimates for a forest graph of male and female victim reactions to robbery and burglary conferences, on the issue of whether they experienced a before-to-after change on the question of "why me?"- why the criminal selected them as the target of the crime.

\section{Results}

\section{Impact of RJ on Victim's Fear of the Offender}

Figure 1 indicates that the proportion of victims afraid of their offender before $\mathrm{RJ}$ was far higher than it was afterwards. This constant pattern is found despite the fact that the baseline fear levels vary across sites. That variation, in turn, may be closely connected to the seriousness of the offense the victims experienced. 


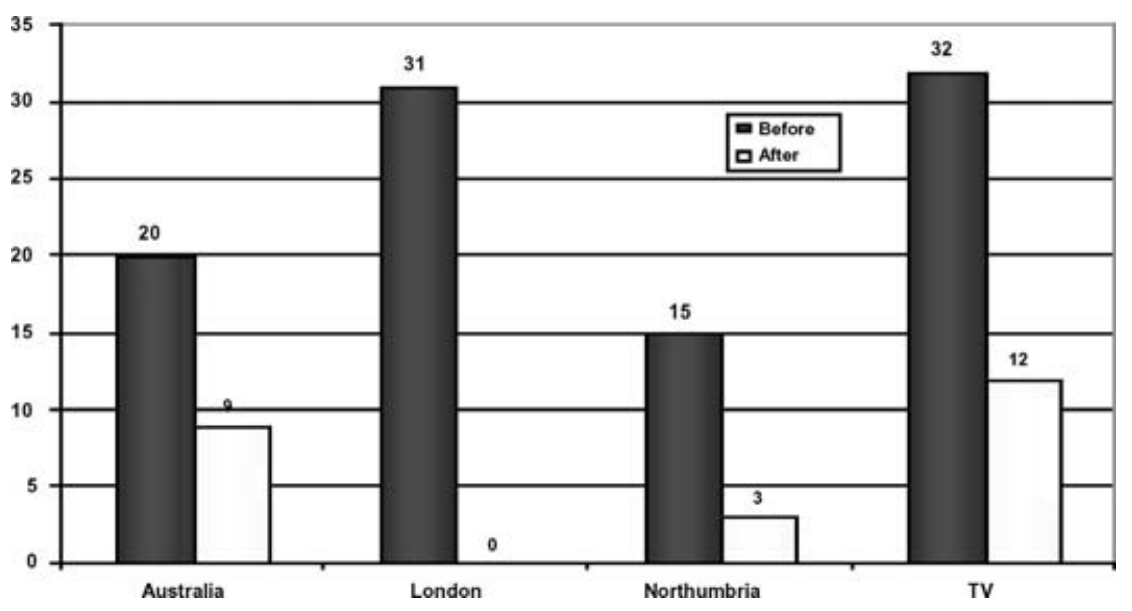

Fig. 1. Percentage of victims afraid before/after RJ conference. Preliminary UK \& RISE.

Both the London and the Thames Valley experiments, where fear levels before RJ exceeded $30 \%$, dealt with very serious crime, most of it with enough violence to result in terms of imprisonment. In contrast, the fear baselines in Canberra and Northumbria, where the offenses in the sample almost never resulted in imprisonment, were only half as high as in London and Thames Valley.

Despite these baseline differences, in all sites there was a dramatic reduction in victims' fear of their offenders after the RJ conference compared to their reported level of fear before the conference. In the case of London, where the largest overall proportional drop (100\%) occurred, not one robbery or burglary victim felt afraid of their offender after the conference. The Canberra figures are an aggregate of the two kinds of offenses in RISE: When this is disaggregated we find that only $4 \%$ of property victims said they felt afraid, compared with $38 \%$ of violence victims. Likewise, the Northumbria figure applies mainly to victims of violence: The highest proportion of victims afraid beforehand were those in the Adult Assault Caution study, which, as we have seen, mostly related to neighborhood disputes, and post-RJ none of these victims said they were still afraid.

For many victims it seems the fearfulness of their offender is much greater in the abstract than in reality. The opportunity an RJ conference presents for victims to make a personal assessment of their offender cannot be overestimated in reducing their fear, as the following case illustrates (names of participants have been changed).

John was a victim of a violent knifepoint robbery. He was a businessman who spent his working week in London and returned to Portsmouth on the weekends where his family resided. He had been walking home from work with his briefcase 
over his shoulder when he was approached by two men. The first man walked up to John and said: "Give me all your money or you're dead" and grabbed hold of his arm. John swore at the men and started to struggle when the second man produced a large machete and put it first to his throat and then slashed his forehead. John fell and the men ran off with his briefcase. A witness came and helped John and police arrived shortly afterwards. One of the offenders was caught near the scene and arrested.

Several months later, John was contacted about participating in a RJ conference with the offender, Khalil. John spoke to the facilitator for several hours. He stated that his whole life had changed. Previously a confident man, he was no longer able to work. He suffered from panic attacks when he went outside and especially when he saw groups of non-white male youths. As a result, he had to be escorted by his son or wife everywhere. In addition, he had a daily reminder of the offense when he looked in a mirror and saw the large scar on his face left by the machete. The facilitator also spoke to John's wife, Pat, who said that her husband was simply not the man he used to be and that he suffered from terrible nightmares that meant that she could no longer sleep next to him. Pat and John agreed to meet the offender who was remanded in custody. Both wanted an opportunity to tell Khalil how he had destroyed their lives.

The conference took place a week later and started as most do-introductions and a reminder that everyone would have an opportunity to hear what had happened, describe how they were affected, and how to make things better. Khalil was present with his mother and brother. He was visibly shocked when he saw the scar on John's face. He broke down in tears and said that he had no idea that his friend had the machete and could not believe how the theft had escalated into the violent attack. Khalil accepted total responsibility for the crime however, and could not stop apologizing for his actions. He asked for John's forgiveness.

John's transformation in the conference was plain to see. His voice shook at the beginning but grew steadier with every word. His slumped body sat tall in his chair by the end of the conference. John asked questions relating to Khalil's background, why he had been committing crime, and why John had been singled out. John and Pat explained in detail how they had been affected. The offender's mother started to cry and Pat reached out and held her hand. By the end of the conference, everyone had exhausted what they had come collectively to say. Khalil apologized again and John and Pat said they forgave him.

After the conference, John and Pat went to the scene of the crime before returning to their home. The facilitator stayed in contact with them both. A few months on, John was working again, he no longer needed to be escorted by his family and his nightmares had subsided. Pat and John had been to an anti-racism rally. John said that the conference had been instrumental in his ability to put the crime behind and move forward with his life. 
In addition, John knew that by meeting Khalil they had made a difference to Khalil's life as well. During the conference, Khalil agreed to apply for high school courses and continue drug counseling. Since the conference, Khalil had committed to random weekly drug tests and had certificates from drug courses and counseling. On his release he undertook a preliminary university course in psychology/criminology.

Fear can be a huge emotional burden in much less serious crime as well. Consider the following case that involved only school girls in a trivial dispute but that had enormous emotional consequences for the victim.

Three girls had admitted to their families and to the police that they had been involved in a fight with the victim during the lunch break at school. The conference was attended by 14 people including the families of all parties and staff from the school. The offenders said that the victim had spread an untrue rumor that one of the offenders was pregnant but it became clear during the conference that they had not told the whole truth about what had happened. Nor had they revealed how seriously the victim had been assaulted: she had been taken to hospital and had a foot mark on her neck where she had been kicked. Her mother told of her shock at the seriousness of her daughter's injuries and that for some time the hospital had been concerned of permanent spinal damage. The victim had been too frightened to go to school since the incident. When they saw for themselves the consequences of the assault the offenders were filled with remorse. They apologized to the victim again and again: the victim responded 'I want to believe you but I' $m$ scared to.' The participants agreed that the offenders should seek counseling through the school and attend anger management classes, that the victim should attend a course to develop her sense of self-worth, and that the families of all the girls would be informed of the victim's progress. None of these undertakings was complied with but in spite of that the victim reported that immediately after the conference she returned to school and was no longer afraid.

\section{Impact of RJ on Anger at the Offender}

Figure 2 shows that in all four research sites, victims reported substantial reductions in their level of anger at offenders after the RJ conference in comparison to their level of anger before the RJ. This pattern held constant despite large differences in baseline levels of anger. The levels were not, as in the case of fear, directly related to the seriousness of the offending. The angriest victims were found in Northumbria where many of the offenses were committed by juvenile offenders (in the two youth "Final Warning" offense categories) or by people with whom they were acquainted (Adult Assault Caution Study). It was with the young offenders that these victims most often felt angry $(87 \%)$, but it was here that the effect of the RJ conference was most dramatic: Only $17 \%$ were still angry afterward. The victims in Thames Valley were less angry than their counterparts in the other sites, 


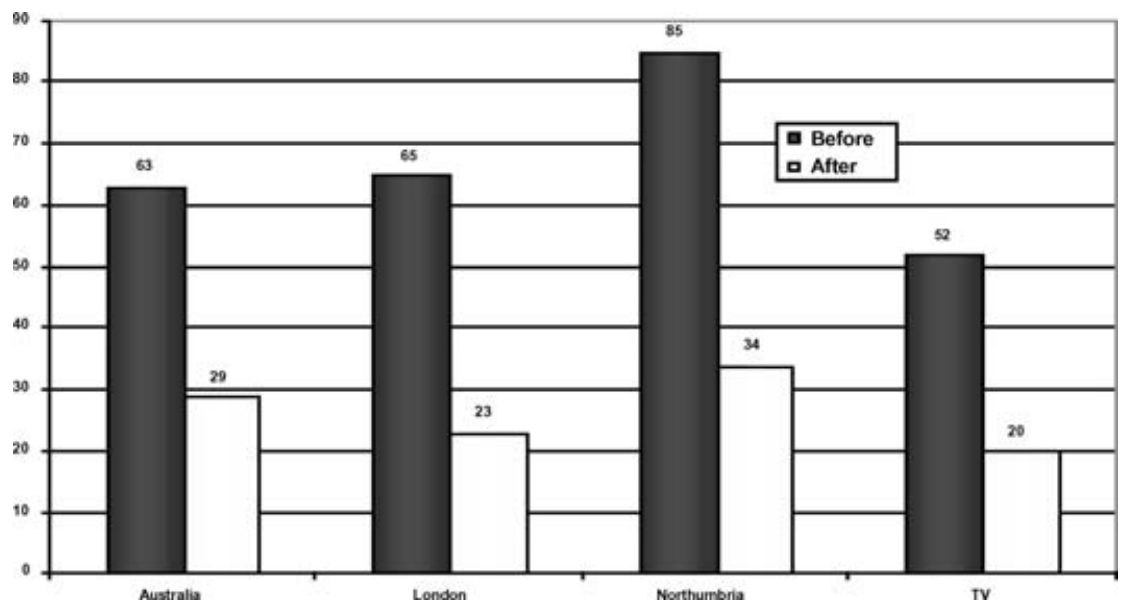

Fig. 2. Percentage of victims angry before/after conference. Preliminary UK \& RISE.

even though they had suffered some of the most serious crime. It seems that in these more serious cases fear was much more salient than anger.

Regardless of baseline levels of anger, the great majority of victims in all four sites reported that after the RJ conference they felt much less angry toward their offender than they had felt beforehand. The following case demonstrates how this can happen.

Joe drove taxis in the evening to supplement the family's income. He did not enjoy the work and had had several unpleasant experiences with drunken and abusive passengers. He had picked up Michael at the end of a long night with few fares. When they reached the destination Michael punched Joe in the face and stole his takings. Joe sustained a broken nose and other facial injuries for which he may need further surgery and which kept him from working for several weeks, causing serious financial problems. Michael was later arrested and charged with robbery.

When the facilitator contacted Joe to ask him to participate in an RJ conference he at first refused point blank. He said he was so angry over the incident that he could not trust his emotions if he saw Michael again. The facilitator suggested that Michael needed to know how much harm had ensued from the incident and Joe finally agreed to attend, mainly for his family's sake. Joe's wife, Sue, had been terrified when she heard about the incident. She was always extremely anxious about Joe's taxi-driving, knowing that it was risky and that he had already had several bad experiences. Their young children were worried too because of their mother's fears. She said she could never sleep properly when he was out driving and now it was impossible because of her fear about his welfare. They both agreed 
that it could be good for them to tell Michael how angry they both felt about the incident and what the consequences had been for the whole family.

Michael arrived at the conference with his parents. He was extremely nervous and was visibly shaking. His parents, clearly mortified by their son's actions, were pale and quiet. Joe could hardly stay in his seat when they entered the room. Before the facilitator could formally begin the meeting Joe launched into a tirade at the offender, shouting and pointing at him. Michael sat silently with his head down for five minutes then got up to leave the room saying that he couldn't stand it. His father got up with him and persuaded him to stay. The facilitator talked quietly to Joe about the purpose of the meeting, as did Sue who was very upset at her husband's behavior. Michael's father said that he and his wife felt extremely ashamed of their son's actions but begged Joe to hear him out.

Michael described his drug-taking over the previous two years, since he had left school. He had been introduced to crack cocaine by friends and now realized that he had a serious problem and was voluntarily attending a drug counselor. He knew he was a different person when he was on a high and also when he was withdrawing and needed another hit. He said that he had managed pretty well up to the time of the incident, holding down a job and earning enough money for his habit. This was the first time he had robbed. He had not taken any drugs since that night as he was so overwhelmed with shame about what had happened.

Joe had listened to Michael quietly at first but his anger kept breaking through. He interrupted constantly and said repeatedly there was no excuse for his actions and for the pain he had caused Sue. Michael was sobbing as he tried to describe his circumstances at the time of the incident. His parents sat helpless, torn between their sympathy for Joe and his wife and their feelings for their son. At this point Sue intervened and told Joe that this was enough, that she did not want to hear any more of his fury and that his temper was part of their difficulties. She got up and left the room, followed by Michael's mother. They smoked a cigarette together and then returned. Joe seemed shaken by his wife's actions and he sat quietly listening to the rest of what Michael and his parents had to say. As he listened he appeared to change his demeanor. At last he said that even though he could not forgive what had happened he now had a clearer understanding of how the incident had come about. He was touched by the love Michael's parents felt for him: Sue observed that even though their children were only small she realized that there were no guarantees with children and she might one day be sitting where they sat. This caused Joe to reflect along the same lines. Even though his anger meant he felt little sympathy for Michael, he could identify with his parents and this seemed to cool his rage. Finally Joe was calm enough for Michael to offer an apology, which he did repeatedly and which Joe and his wife accepted. It was agreed that Michael should continue treatment to ensure that he remained drug-free and that he should write a letter to Joe and Sue twelve months hence and tell them how he was dealing with his addiction. The formal part of the conference closed but 


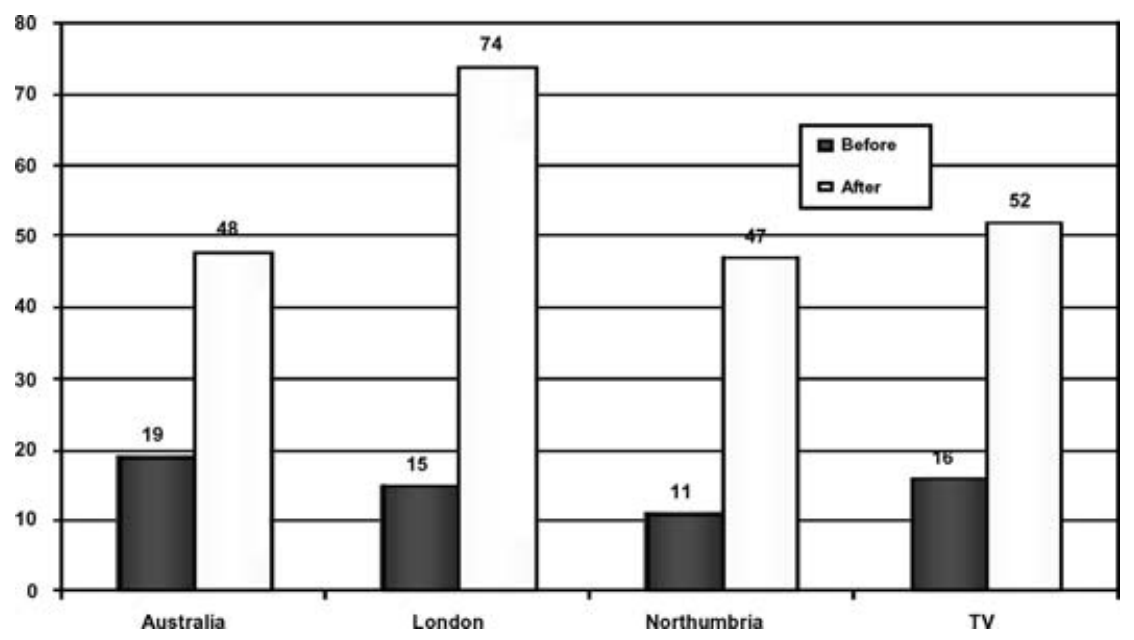

Fig. 3. Percentage of victims sympathetic before/after conference. Preliminary UK \& RISE.

everyone stayed for a cup of tea. Sue and Michael's mother immediately fell into conversation about children while Joe and Michael's father stood talking about football, with Michael awkwardly standing by. A few days later Michael appeared in court for sentence. After taking into account Michael's previous good record and his participation in restorative justice the judge gave him a non-custodial sentence. One year later Michael had not been arrested again.

\section{Impact of RJ on Sympathy for the Offender}

Figure 3 shows that victims report an almost three fold average increase in their feelings of sympathy towards offenders from before the RJ conference to after the RJ. This consistent pattern varies only in magnitude, from a fairly low level of sympathy in all four samples.

Although we do not advocate sympathy as necessarily a good in its own right, we do see it as a precursor to forgiveness. Again, we do not see that victims should be under any obligation to forgive their offenders, but there is evidence to suggest that this may have real benefits for victims' welfare in the long term (Angel, 2005). In any event, across all sites it was clear that victims who had had the opportunity to assess their offenders' circumstances and character for themselves over the two hours or so of scrutiny that the RJ conference provided, tended to feel much more sympathy than they had felt beforehand. This was particularly striking in the case of the very serious offenses being dealt with in London, although it happened in less serious cases too, such as the one described here, 
where the legal harm is relatively small but the consequences for the victim were life-changing.

Two 12-year-old brothers had thrown a stone at a bus and smashed a window, showering the driver and passengers with glass. The conference was attended by the bus driver and Mrs Jones, an elderly lady who had been a passenger on the bus. She had not been named on the police report, but the bus driver knew her because she took his bus to bingo every week. He was worried about her because he hadn't seen her since it happened-she no longer went out unless she had to as she was so shaken by the incident. The facilitator eventually located Mrs Jones and invited her to participate in a conference. She readily agreed to attend the conference because she was very cross with the two young boys. She was completely unsympathetic towards them and wanted to give them a piece of her mind.

At the conference Mrs Jones was hard on the young boys and pushed them to find out why they had done what they did. The boys engaged with her and answered all her questions. As the conference went on Mrs Jones began to soften towards the boys. When the manager of the bus station suggested that the boys could pick up litter at the bus station on a Saturday she encouraged them to do that as she thought that part of their problem was that they didn't have enough to do with their time. The boys' mother suggested that the boys could buy Mrs Jones chocolates or flowers but she said that she didn't need them. But she said that she felt that she would now be able to go back on the bus again.

At the end of the conference, after the boys had apologized, their mum suggested that they give the lady a hug-at this the boys jumped up and ran over and the hug went both ways between Mrs Jones and the boys. The following week she said that she had been back on the bus and back to the bingo and was feeling much better about everything. The boys went to the bus station for eight Saturdays for two hours at a time and completed their agreement.

In this context it is interesting to note that empirical evidence supports the theory that RJ provides a better opportunity for empathy to occur than normal criminal justice processing through the courts. Among offenders in the Canberra RISE, Harris (2002) found more offender empathy for their victims in RJ than in court. But a more interesting question is whether empathy on one side can elicit or reinforce empathy on the other side. In RISE, offenders were asked whether they understood what it actually felt like for those who had been affected by their actions, while their corresponding victim-pair was asked whether they felt the apology they had received was sincere. In almost two-thirds of all cases randomly assigned to a RJ conference, both parties answered yes, while for those assigned to court, only $15 \%$ did so (Strang, 2002). There was certainly a strong tendency in these conferences for empathy felt by one party to influence the other party to feel empathy as well. 


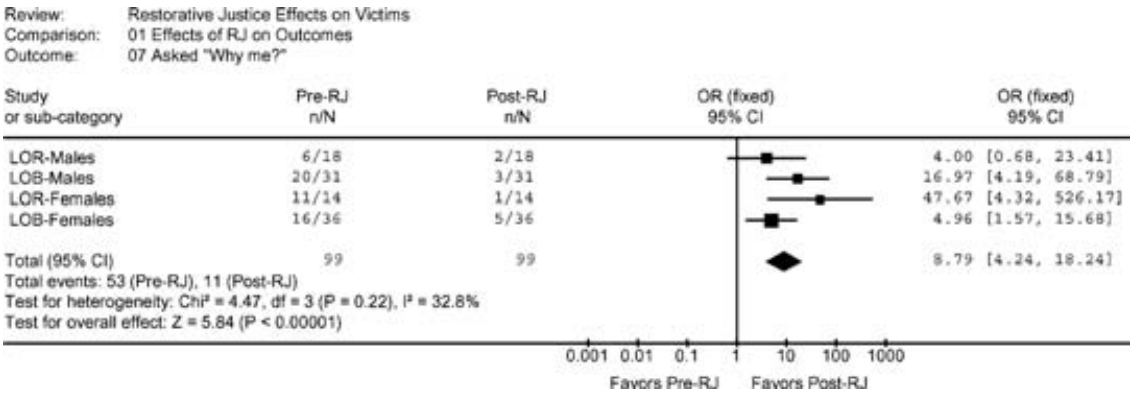

Fig. 4. Asked "Why me?"

Impact of RJ on Reducing Apprehension about "Why me?"

Figure 4 shows that victims of both genders in both London experiments felt much better after the RJ conference than before about the question of "Why me?" in the offender's choice of target. The figure is a forest graph in which each point estimate is an odds ratio, surrounded by confidence intervals. While the confidence intervals for one point estimate cross the middle line representing zero, the overall pattern of point estimates is not likely to have been due to chance; it is statistically significant at below .05. The respondents in all four point estimates had all been randomly assigned to the RJ group.

The vast majority of both male and female victims in both burglary and robbery said that they felt this fear had been satisfactorily addressed by the conference. The emotional relief that victims experienced is summed up by the victim who said: "I thought it was a good idea to take part [in the conference]: I wanted to know why he beat me up and I got the answer in the conference. The only time I saw him after he beat me up was at court and I couldn't ask him in court why he did it." It is also evident in the following case.

Nancy had been the victim of an artifice burglary. Her offender had conned his way into her house and while Nancy made him a cup of tea he stole her purse, mobile phone, and jewellery of great sentimental value. Nancy was devastated by the burglary and as a result lost all confidence in herself and found it really difficult to leave her house. She had always enjoyed speaking with young people but she had now become very mistrustful. It also affected her relationship with her daughter and although the two were normally very close, a rift had developed with each one not knowing how to speak to or comfort the other. Nancy agreed to attend the conference with her daughter and her experience had very positive results. In the course of the conference Nancy found out that she had not been targeted and this was important in restoring her sense of security. She also was able to tell the offender how much the jewellery he had taken had meant to her 
Table 2. Victims Reactions to RJ

\begin{tabular}{lcc}
\hline & London $(N=134) \%$ & Northumbria $(N=130) \%$ \\
\hline Did the conference go well? & 96 & 92 \\
Able to say what you wanted? & 99 & 90 \\
Pleased with what offender said? & 82 & 81 \\
Pleased with outcome? & 91 & 85 \\
Given enough information? & 94 & 92 \\
Any negative consequences after RJ? & 10 & 3 \\
Felt had a choice about participating? & 98 & 92 \\
Would you do it again? & 87 & 92 \\
Would you recommend & 84 & 92 \\
$\quad$ anyone else to do it? & & \\
\hline
\end{tabular}

and her family. Both the offender and his mother talked about the steps they would take to recover the jewellery. Following the conference, Nancy's daughter called to say that her mother's confidence had returned, that she felt comfortable again talking to young people and that she and her mother had been able to talk openly about the burglary and its effect on them.

\section{Other Findings on Victim Reactions to RJ}

We are able to supplement these specific findings about emotional reactions of victims to their offenders with some general findings from London and Northumbria about victim satisfaction with their RJ experience (no data are available from Thames Valley; victims in Canberra were asked slightly different questions on this topic and their responses were broadly in line with those reported here (Strang, 2002)). These telephone contacts were made $2-6$ weeks post-RJ.

These results reveal an extraordinarily high level of general satisfaction by victims who agreed to participate. The fact that responses are so alike in two such disparate settings as London and Northumbria, and elicited from victims of quite different offenses and offenders, is a strong endorsement of the effectiveness of the RJ process in giving victims what they need.

A female burglary victim offered the following response to her conference:

"I think we got a lot out of the conference. I had been having bad dreams and a bad reaction to the crime in general. This was really an opportunity to face demons and it is a quite a powerful thing to do and helps you to move on. There were things that came out in the conference that I didn't realize until I was there and this gave me and my husband things to talk about when we got home. The conference was quite cathartic...I definitely feel I am moving onto a different phase, just recently. I think this whole system is brilliant in making people face up to what they have done-there doesn't seem to be anything else like it. He was very remorseful and did realize what he had done. One of his family members and others came out to support him ... they did not agree with how he was living his life."

Another burglary victim echoed a similar sentiment of emotional restoration and hope for the offender's future: 
"It was really interesting. It was quite hard work though-like being in therapy for two and a half hours. It was sad, but in the end it was quite empowering because it does help you to move on. I now understand "why" ... you could see in him that something during the conference, something clicked."

\section{Discussion}

Our objective across all of these studies has been to test the effects of faceto-face RJ conferences as a civil society institution, under as many conditions as possible. These four sites-Canberra, Australia and London, Northumbria, and the Thames Valley region in the United Kingdom-are extraordinarily diverse on many dimensions. They vary dramatically in their social contexts, in the nature of their communities, in their cultural diversity, in victim and offender demographics, and in the seriousness of the offenses where RJ was offered. They also varied in the stage of the criminal process at which RJ conferences occurred, from immediately after arrest to well after conviction and many months served in prison.

These variations make all the more striking the consistency of the findings about victims' emotional reactions to participation in this kind of RJ. Preliminary data from controlled tests of RJ indicate that offenders' reactions to RJ, as measured by repeat offending, are highly variable (Sherman \& Strang, 2004), depending on race, gender, social context, type of offense, and other variables still unspecified. But the victim reaction data presented here reveal that victims of all kinds of backgrounds and circumstances and all kinds of offenses achieve a substantial degree of emotional recovery from RJ. While these effects may be subject to rival alternative interpretations because they lack appropriate controls, the evidence does provide a strong initial indication that the controlled tests may uncover even larger or more long-lasting effects.

$\mathrm{RJ}$ conferences clearly provide victims with the potential at the least to get more of what they want from criminal justice. Research over the past 20 years (Shapland, Willmore, \& Duff, 1985; Lurigio \& Resnick, 1990; Umbreit, 1994; Strang, 2002) is remarkably consistent in its findings that what victims want most is different from what the formal justice system assumes is important for them. Victims consistently report that they value highly the opportunity for meaningful participation in their cases, with the chance to ask the questions that are important for them, that they want information about the way their cases are being dealt with, and they want to be treated respectfully and fairly.

But it is the need for emotional restoration that emerges most strongly. As this research program has reported elsewhere (Strang, 2002), victims consistently report that emotional restoration is what they desire most from their "justice" experience and what they so rarely find in the formal justice system. A preference for apology over money or vengeance is consistently reported in our RJ research (Sherman et al., 2006). Most victims of a wide range of crimes, even those causing 
substantial injury, focus far more on the offenders' statements of understanding the harm they caused and expressions of remorse for having caused it. We have repeatedly observed that when offenders bring up compensation first, victims usually divert that issue until a full and emotionally painful discussion of the harm has been completed. Even when that discussion is finished, victims tend to focus much more on how future crime can be prevented than on their own material reparation, by addressing offenders' rehabilitation and reintegration. All of this, in turn, places the victim in the morally powerful position of shaping the future, in relation to the past moral weakness of the offender. The story of John and Khalil illustrated many of these dynamics and the enormous difference between the nuanced emotions of this victim and the crude view that victims merely want vengeance.

The measures reported here about changes in victims' emotions towards their offenders relate to a subset of all the victims in our experiments. In Canberra the respondents were all the victims whose cases had been randomly assigned to an RJ conference that had in fact taken place. In the three U.K. sites the respondents were those whose cases were in the pre-random assignment stage of each of the experiments subsequently conducted in each site: They were "test" cases to the extent that they were used to test the referral process from criminal justice agencies to the researchers and were not randomly assigned in the way that the experimental cases were.

There is no reason to believe, however, that the victims in these cases differed in theoretically relevant ways from the victims in the experimental cases. We therefore contexualize their responses within the bigger picture of the responses of victims in the randomly assigned experimental cases to questions about their satisfaction with the entire RJ process. When we take these two kinds of data together-practical and emotional—we find an extraordinary level of satisfaction among these victims.

Our results, as in all RJ, apply only to those victims who agreed to participate. We found varying levels of reluctance by victims to encounter their offenders, whether from anger, fear, or any other emotion. The level of reluctance appears to depend on the social setting (with the highest victim takeup rates in Canberra) and perhaps on seriousness of the offense. We do not know whether these victims had the capacity to self-select in such a way that they were more likely to benefit than victims who declined to participate. Nor is there reason to think that RJ is a remedy suitable for every victim. Our data show that for a small minority within our studies, RJ was a negative experience that did not improve their situation and may have made it worse. Conferences are inherently more volatile ventures than normal criminal justice processing: The latter may do little to help victims but little to harm them either, whereas confronting an unremorseful offender may be a significant risk, even when the payoff is substantial if the encounter results in a sincere expression of apology. At present we do not have the tools to predict 
for whom RJ is likely to be beneficial and for whom it will be counterproductive. Nevertheless, such strong and consistent positive finds about victim benefits in the great majority of cases leads us to recommend that victims should be encouraged to participate whenever they have the opportunity to do so.

\section{Conclusion}

Crime victims consistently say they are better off after joining in a civil society institution of face-to-face RJ than they were before. Regardless of the kind of crime they have suffered, the kind of community they live in, the point in the criminal justice process, or the physical location of the conferences, victims who have taken part in RJ report very positive experience. This conclusion applies to almost every criterion on which data are available. This evidence, combined with findings from RCTs reported elsewhere, builds a firmer evidence base on which policy decisions about RJ can be made. For as long as RJ does not increase repeat offending relative to conventional justice, there is a clear victim benefit returned on investments in RJ. Specifying that benefit in terms of medical or employment costs is the subject of ongoing research. So too is the identification of offenses and offenders for whom RJ may indeed increase repeat offending. Few crime victims would want any program to cause more crime, regardless of how much it may benefit them personally. Yet if research can indicate when victims can be helped without causing more crime, RJ may be a public policy of the future as an instrument of civil society with the potential to capture the strengths of both the formal justice system and of victims' and offenders' personal communities.

\section{References}

Angel, C. (2005). Crime victims meet their offenders: Testing the impact of restorative justice conferences on victims' post-traumatic stress symptoms. Ph.D. Dissertation, University of Pennsylvania.

Blumer, H. (1969). Symbolic interactionism: Perspective and method. Englewood Cliffs, NJ: Prentice-Hall.

Braithwaite, J. B. (1989). Crime, shame and reintegration. Cambridge, UK: Cambridge University Press.

Braithwaite, J. B. (2002). Restorative justice and responsive regulation. Oxford, UK: Oxford University Press.

Brand, S., \& Price, R. (2000). The economic and social costs of crime. Research Study 217. London: Home Office.

Buchan, J. (2004). Crowded with genius. New York: Harper Collins.

Collins, R. (2004). Interaction ritual chains. Princeton, NJ: Princeton University Press.

Durkheim, E. (1965). The elementary forms of religious life. New York: Free Press.

Foa, E. B., \& Meadows, E. A. (1997). Psychosocial treatments for posttraumatic stress disorder: A critical review. American Review of Psychology, 48, 449-480.

Foa, E. B., \& Kozak, M. J. (1986). Emotional processing of fear: Exposure to corrective information. Psychological Bulletin, 99, 20-35.

Gehm, J. (1990). Mediated victim-offender restitution agreements: An exploratory analysis of factors relating to victim participation. In B. \& J. Hudson (Eds.), Criminal justice restitution and reconciliation. New York: Criminal Justice Press. 
Harris, N. (2002). Shaming and Shame: Regulating Drink-Driving. In E. Ahmed, N. Harris, J. Braithwaite, \& V. Braithwaite (Eds.), Shame management through reintegration. Cambridge, UK: Cambridge University Press.

Lurigio, A. J., \& Resnick, P. A. (1990). Healing the psychological wounds of criminal victimization. In A. J. Lurigio, W.G. Skogan \& R. C. Davis (Eds), Victims of crime: Problems, policies and programs. Newbury Park, CA: Sage Publications.

McCold, P. (1997). Restorative justice, variations on a theme. In L. Walgrave (Ed.), Restorative justice for juveniles: Potentialities, risks and problems for research. Leuven: Catholic University of Leuven.

McGarrell, E. F., Olivares, K., Crawford, K., \& Kroovand, N. (2000). Returning justice to the community: The Indianapolis juvenile restorative justice experiment. Indianapolis, IN: Hudson Institute Crime Control Policy Center.

Miers, D., Maguire, M., Goldie, S., Sharpe, K., Hale, C., Netten, A., Uglow, S., Doolin, K., Hallam, A., Enterkin, J., \& Newburn, T. (2001). An exploratory evaluation of restorative justice schemes. Crime Reduction Research Series Paper 9. London: Home Office.

Putnam, R. (2000). Bowling alone: The collapse and revival of American community. NY: Simon \& Schuster.

Rothbaum, B. O., \& Foa, E. B. (1999). Exposure therapy for PTSD. PTSD Research Quarterly. 10(2), $1-6$.

Shapland, J., Willmore, J., \& Duff, P. (1985). Victims in the criminal justice system. Cambridge Studies in Criminology. Aldershot: Gower.

Sherman, L. W. (1993). Defiance, Deterrence and Irrelevance. Journal of Research in Crime and Delinquency, 30, 445-473.

Sherman, L. W., \& Strang, H., in collaboration with Woods, D. J., Angel, C., Barnes, G. C., Inkpen, N., Newbury-Birch, D., Bennett, S. B. (2004). Restorative Justice: What we know and how we know it. Philadelphia: University of Pennsylvania, Jerry Lee Center of Criminology, http://www.sas. upenn.edu/jerrylee/rjWorkingPaper1.pdf.

Sherman, L. W., Strang, H., Angel, C., Woods, D. J., Barnes, G. C., Inkpen, N., \& Bennett, S. B. (2005). Effects of face-to-face Restorative Justice on victims of crime in four randomized, controlled trials. Journal of Experimental Criminology, I(3) (forthcoming).

Strang, H. (2002). Repair or revenge: Victims and restorative justice. Oxford, UK: Oxford University Press.

Strang, H., \& Sherman, L. W. (2003). Repairing the harm: Victims and restorative justice. Utah Law Review, 1, University of Utah.

Tyler, T. (1990). Why people obey the law. New Haven, CT: Yale University Press.

Umbreit, M., Coates, R., \& Kalanj, B. (1994). Victim meets offender: The impact of restorative justice and mediation. Monsey, NY: Criminal Justice Press.

Wilcox, A., Young, R., \& Hoyle, C. (2004). An evaluation of the impact of restorative cautioning: Finding from a reconviction study. Home Office Research Findings 255. London: Home Office.

HEATHER STRANG is Director of the Centre for Restorative Justice at the Regulatory Institutions Network, Research School of Social Sciences, Australian National University, and co-director of the Jerry Lee Program on Randomized Controlled Trials in Restorative Justice. Since 1995 she has been managing studies investigating the effectiveness of restorative justice. She has a special interest in victims of crime, which is the focus of her own research. Her book, Repair or Revenge: Victims and Restorative Justice, was published in 2002.

LAWRENCE W. SHERMAN is Director of the Jerry Lee Center of Criminology and Chair of the Department of Criminology at the University of Pennsylvania, where he is the Albert Monroe Greenfield Professor of Human Relations. He has designed and directed over 25 randomized controlled trials in crime and justice, 
including the Jerry Lee Program of Randomized Controlled Trials in Restorative Justice. He is a Fellow, Sutherland Award winner, and Past President of the American Society of Criminology, and was the founding President of the Academy of Experimental Criminology.

CAROLINE ANGEL was awarded the PhD in nursing and criminology in 2005 from the University of Pennsylvania, where she is a research consultant in the Jerry Lee Program on Randomized Controlled Trials in Restorative Justice at the Jerry Lee Center of Criminology.

DANIEL J. WOODS is a PhD candidate in criminology at the University of Pennsylvania and a research associate in the Jerry Lee Program on Randomized Controlled Trials in Restorative Justice at the Jerry Lee Center of Criminology.

SARAH BENNETT is Assistant Director of the Justice Research Consortium - UK for the Jerry Lee Program on Randomized Controlled Trials in Restorative Justice at the Jerry Lee Center of Criminology and a $\mathrm{PhD}$ candidate in criminology at Cambridge University.

DOROTHY NEWBURY-BIRCH is Assistant Director of the Justice Research Consortium - UK for the Jerry Lee Program on Randomized Controlled Trials in Restorative Justice and a research consultant to the Centre for Restorative Justice, Regulatory Institutions Network, Research School of Social Sciences, at the Australian National University.

NOVA INKPEN served from 2001 to 2005 as Assistant Director of the Justice Research Consortium - UK for the Jerry Lee Program on Randomized Controlled Trials in Restorative Justice at the Centre for Restorative Justice, Regulatory Institutions Network, Research School of Social Sciences, Australian National University. 